\title{
Suitability of Irbid Clay as Compacted Liners for Landfill, Jordan
}

\author{
Omer S. Mughieda ${ }^{1}$, Munjed Al-Sharif ${ }^{2}$ \\ ${ }^{1}$ Department of Civil Engineering, Abu Dhabi University, Abu Dhabi, UAE \\ ${ }^{2}$ Department of Civil Engineering, German Jordanian University, Amman, Jordan \\ Email: omer.mughieda@adu.ac.ae
}

Received September 6, 2013; revised October 7, 2013; accepted November 4, 2013

Copyright (C) 2013 Omer S. Mughieda, Munjed Al-Sharif. This is an open access article distributed under the Creative Commons Attribution License, which permits unrestricted use, distribution, and reproduction in any medium, provided the original work is properly cited. In accordance of the Creative Commons Attribution License all Copyrights (C) 2013 are reserved for SCIRP and the owner of the intellectual property Omer S. Mughieda, Munjed Al-Sharif. All Copyright (C) 2013 are guarded by law and by SCIRP as a guardian.

\begin{abstract}
The goal of this study is to investigate the possibility of using the Irbid city clayey soil as compacted clay liner. The geotechnical properties and the permeability characteristics of compacted clayey soil sample obtained from the eastern part of Irbid city were determined to evaluate their suitability as compacted clay liner. Falling head permeability test, unconfined compressive strength and volumetric shrinkage test were conducted on soil samples that were compacted at about $0 \%$ and $3 \%$ wet of its optimum water content. The leakage rates expected through clay-only and composite geomembrane-clay liners were determined. It could be concluded based on the results of the geotechnical tests and leachate rate calculations that Irbid clay is appropriate to be used as compacted landfill liner material.
\end{abstract}

Keywords: Liner; Compacted Clay; Landfill; Geomembrane; Leachate; Irbid Clay

\section{Introduction}

Jordan is a country with limited natural resources and high population growth due to the three waves of immigration resulting from the Gulf wars, the occupation of Iraq, and the Palestinian conflict. This, together with many other economical, political, and social factors, has created many environmental threats to the environment of Jordan, especially in the area of water pollution and solid waste sector. The average solid waste generation in Jordan ranges from 0.72 to $0.92 \mathrm{~kg} / \mathrm{cap} /$ day. The total estimated daily generation of municipal solid waste in Jordan is about 3700 tons/day. The northern region contributes about 800 tons daily. The solid waste generated at the northern region of Jordan is disposed of at Al Akaider landfill located about $25 \mathrm{Km}$ to the east of the city of Irbid. Figures 1 and $\mathbf{2}$ show the location of Al Akaider landfill. Solid waste deposition in this landfill starts in 1981 and it is expected that it will at least stay in service until 2020.

The typical composition of solid waste received at $\mathrm{Al}$ Akaider landfills is: $16 \%$ paper, 7\% glass, 5\% metal, plastics $13 \%$, food waste $56 \%, 1 \%$ metal, and many other things at $2 \%$.

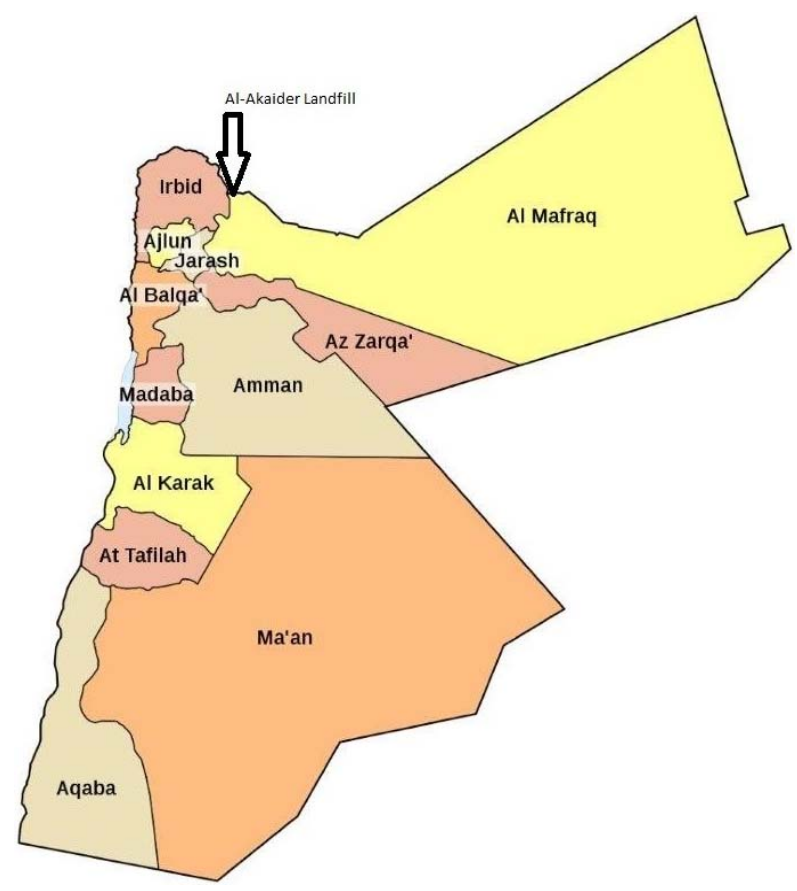

Figure 1. Jordan map and location of Al Akaider Landfill location. 


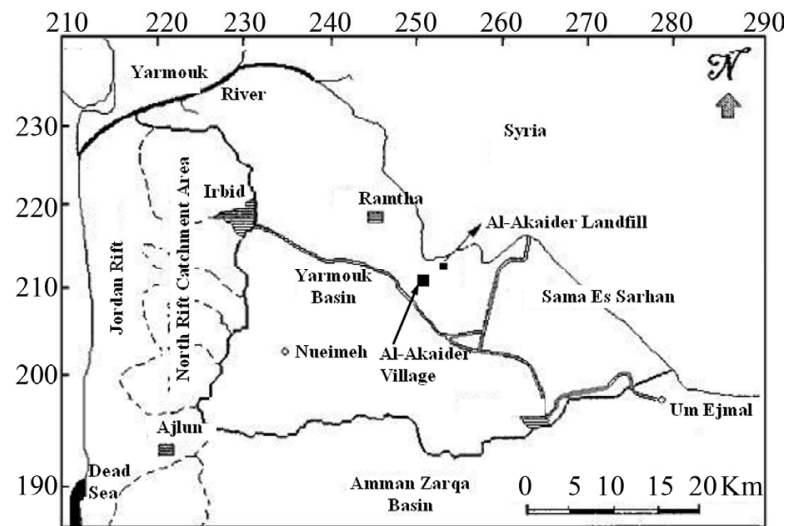

Figure 2. Detailed map of Al Akaider Landfill location.

The topography of the area is a mix of hilly and semiflat about $650 \mathrm{~m}$ above sea level. The aquifer system in the study area is considered as confined aquifer with a depth to the saturated zone ranging from 330 to $450 \mathrm{~m}$ below the ground surface. Due to the lack of major faults in the site, chances for direct connection between pollutants and the aquifer are slow process. The aquifer moisture absorbency is from the aquifer formation which is from chalk, marl, chalky limestone, and then beds of chert, phosphate and bituminous chalk. The soil in Al Akaider landfill is categorized as silty soil with sand and considered to be a poor landfill liner. Figure 3 shows the geological formation of the Al Akaider landfill. The area of the landfill is classified as an arid region with an average rainfall is about $160 \mathrm{~mm}$ /year, with highest mean annual temperature of $27.4^{\circ} \mathrm{C}$ and lowest mean annual temperature of $8.7^{\circ} \mathrm{C}$.

\section{Geology of Irbid Area}

Jordan is located in a semi-arid area with four distinct seasons in a year. The rainy season is kind of long begins in November and lasts until April. However, Spring is short, followed by a hot dry summer that lasts from May to September. The annual precipitation in Irbid City, north of Jordan, varies from $200 \mathrm{~mm}$ to $800 \mathrm{~mm}$. The clay in the eastern part of Irbid lays in an east west, broad, elongated depression or basin, which runs across the highland plateau area of eastern and southern Irbid. The underlying bedrock is thought to be mostly basalt, which came into the area from north-east as a lava flow during the Tertiary Era. The soil profile consists of 2 - $3 \mathrm{~m}$ of dark grayish brown clay underlain by reddish brown clay down to a depth of $10 \mathrm{~m}$. Then, weathered materials of large rounded boulders of basalt exist just above the clay/basalt interface [1]. According to the Unified Soil Classification System, Irbid clay is classified as high plasticity clay $(\mathrm{CH})$.

\section{Geotechnical Properties of Irbid Clay}

A disturbed soil sample from the eastern part of Irbid at

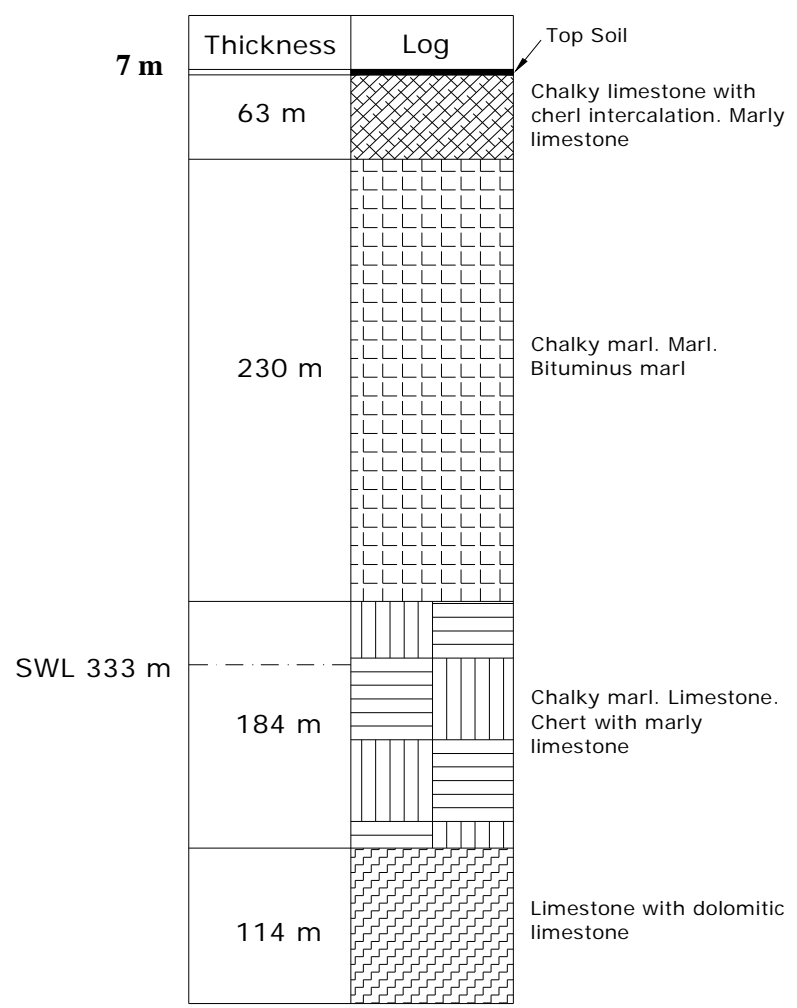

Figure 3. Geological Formation of Al Akaider Landfill.

depth of $2.7 \mathrm{~m}$ was taken and brought to the soil mechanics lab where the required tests have been performed. In Irbid clay samples clay minerals and mica were presents. Of the minerals, clay was dominant and the smectite was the most abundant clay mineral. The percentage of sand, Silt, Kaolinite, Smectite for the studied soil were $2 \%, 36 \%, 13 \%$ and $49 \%$ respectively.

The physical properties were obtained according to the procedures suggested by [2]. Results showed that the bulk and dry unit weights of the clay were between 17.1 $\mathrm{kN} / \mathrm{m}^{3}$, and $15.6 \mathrm{kN} / \mathrm{m}^{3}$, respectively. The specific gravity of soil solids was around 2.8 .

Atterberg limits were determined according to [3]. The results showed that the soil sample has Liquid limit of $72 \%$ Plastic Limit of $32 \%$ and Plasticity Index of $40 \%$. According to the Unified Soil Classification System (USCS), the soil was classified as high plasticity clay $(\mathrm{CH})$.

The compaction curve of the taken soil samples was determined according to the standard proctor method [4]. The results of the standard proctor test show that the sample has optimum water content $\left(\mathrm{w}_{\mathrm{opt}}\right)$ of $17 \%$ and a corresponding maximum dry density $\left(\rho_{\mathrm{dmax}}\right)$ of 1.44 $\mathrm{g} / \mathrm{cm}^{3}$. The hydraulic conductivity of the compacted soil samples was determined at optimum and 3\% wet of optimum water content by using the falling head apparatus in accordance with [5]. The results of the hydraulic conductivity tests conducted at optimum and 3\% wet of op- 
timum water content showed that the compacted soil samples had a hydraulic conductivity of $1.7 \times 10^{-8} \mathrm{~cm} / \mathrm{s}$ and $1.2 \times 10^{-8} \mathrm{~cm} / \mathrm{s}$ respectively. Unconfined compression tests were performed on specimens prepared at optimum and $3 \%$ wet of optimum water content with the corresponding dry density obtained from the compaction test. The results indicated that the soil samples had unconfined compressive strength of $215 \mathrm{kPa}$ and $211 \mathrm{kPa}$ respectively. Volumetric shrinkage tests [6] were conducted on specimens prepared at optimum and 3\% wet of optimum water content showed that the soil samples had volumetric strain of $3.4 \%$ and $3.8 \%$ respectively. [7] suggested that hydraulic conductivity less than $1 \times 10^{-7}$ $\mathrm{cm} / \mathrm{s}$ is required for well designed clay liner. [8] suggested that the unconfined compressive strength of the compacted clay liner should be greater than $200 \mathrm{kPa}$. [8] suggest that an acceptable limiting value of volumetric strain to prevent desiccation for the soil should be less than or equal to $4 \%$.

A well designed compacted clay liner must have a low permeability to prevent or minimize leachate leakage, adequate shear strength for stability, and minimal shrinkage potential to prevent desiccation cracking. The tests results on Irbid clay showed that all suggested requirements are met and that Irbid clay is suitable for utilization as compacted clay liner.

\section{Expected Leakage Rate Calculations}

The procedure by [9] on Ankara clay was used in the present study for calculations of expected leakage rate and leachate collection layer capacity. Leakage rate due to fluid permeation through a compacted clay liner can be calculated from Darcy's law as follows:

$$
q=k_{s} \cdot i \cdot A=k_{s}((h+D) / D) A .
$$

where: $q_{s}$ is the leakage rate through the clay liner; $k_{s}$ is the hydraulic conductivity of the clay; $i$ is the hydraulic gradient $(i=(h+D) / D)$ where: $h$ is the leachate head acting on top of the liner; $D$ is the thickness of the clay liner; and, $A$ is the unit area of the liner considered.

The expected leakage rate through flaws in the geomembrane component of a composite liner may be calculated through assuming good or poor geomembranesoil contact by the following equations proposed by
$[10,11]$ for the rate of leakage through a circular hole in the geomembrane component of a composite liner. These equations are also presented by [12].

$$
q=0.21 \cdot a^{0.1} \cdot h^{0.9} \cdot k_{s}^{0.74} \operatorname{good} \text { contact }
$$

and

$$
q=1.15 \cdot a^{0.1} \cdot h^{0.9} \cdot k_{s}^{0.74} \text { poor contact }
$$

where $q$ is the leakage rate through a hole in the geomembrane component, $\mathrm{m}^{3} / \mathrm{sec}$; $a$ is the area of a circular hole in geomembrane, $\mathrm{m}^{2} ; h$ is the liquid head on top of the geomembrane, $m$ and $k_{s}$ is the hydraulic conductivity of the soil component of the composite liner, $\mathrm{m} / \mathrm{sec}$. [10] define pinhole flaws to be smaller than the thickness of the geomembrane typically having a diameter of $1 \mathrm{~mm}$ and define defects as having a typical diameter of 11.28 $\mathrm{mm}$ or a cross-sectional area of $100 \mathrm{~mm}^{2}$. The unitized leakage rate result for $60 \mathrm{~cm}$ thick clay liner, which is the minimum thickness suggested by United States Environmental Protection Agency (USEPA) [13] having a hydraulic conductivity value of soil samples $1.5 \times 10^{-8}$ $\mathrm{cm} / \mathrm{s}$, subjected to leachate head of $30 \mathrm{~cm}$, different size of holes $\left(0.1,1.0,10 \mathrm{~cm}^{2}\right)$ and different number of holes ( 1 and 30 holes/acre) are shown in Tables 1 and 2. For both good and poor contact conditions. The results of leakage rate for clay-only liner are shown in Table 3. The results of the expected leakage rate calculations presented in Tables 1-3 show that compacted Irbid clay shows the best performance with a geomembrane/clay composite liner system in good contact condition. This system reduces the leakage rate by a factor of about 5.5 when compared to that of composite liner system in poor contact condition. while it reduces the leakage rate by a factor of 755 when compared to that of clay only liner.

\section{Conclusion}

The results of the geotechnical investigations on a clayey soil samples obtained from Irbid area showed that Irbid Clay was very appropriate for being used as a compacted clay landfill liner material. The expected leakage rates through three possible cases were evaluated: clay only, composite liners with poor contact condition and composite liners with good contact conditions. The expected leakage rate calculations show that the expected leakage

Table 1. Calculation for poor contact between the Geomembrane and the underlying soil; $q=1.15 a^{0.1} \cdot h^{0.9} \cdot k_{s}^{0.74}$

\begin{tabular}{cccccccc}
\hline \multicolumn{2}{c}{ Hydraulic Conductivity of Subsoil } & \multicolumn{2}{c}{ Size of Hole in Geomembrane } & Head of Water & Number of Holes & \multicolumn{2}{c}{ Flow Rate } \\
\hline $\mathbf{~ m} / \mathbf{s e c}$ & $\mathbf{m} / \mathbf{s e c}$ & $\mathbf{c m}^{\mathbf{2}}$ & $\mathbf{m}^{\mathbf{2}}$ & $\mathbf{~ m}$ & Holes/acre & $\mathbf{m}^{3} / \mathbf{s e c}$ & $\mathbf{m}^{\mathbf{3}} / \mathbf{d a y} / \mathbf{a c r e}$ \\
\hline $1.50 \mathrm{E}-08$ & $1.50 \mathrm{E}-10$ & 0.1 & $1.00 \mathrm{E}-05$ & $3.00 \mathrm{E}-01$ & 1 & $6.61 \mathrm{E}-09$ & $5.714 \mathrm{E}-04$ \\
$1.50 \mathrm{E}-08$ & $1.50 \mathrm{E}-10$ & 0.1 & $1.00 \mathrm{E}-05$ & $3.00 \mathrm{E}-01$ & 30 & $1.98 \mathrm{E}-07$ & $5.142 \mathrm{E}-01$ \\
$1.50 \mathrm{E}-08$ & $1.50 \mathrm{E}-10$ & 1 & $1.00 \mathrm{E}-04$ & $3.00 \mathrm{E}-01$ & 1 & $8.33 \mathrm{E}-09$ & $7.193 \mathrm{E}-04$ \\
$1.50 \mathrm{E}-08$ & $1.50 \mathrm{E}-10$ & 1 & $1.00 \mathrm{E}-04$ & $3.00 \mathrm{E}-01$ & 30 & $2.50 \mathrm{E}-07$ & $6.474 \mathrm{E}-01$ \\
$1.50 \mathrm{E}-08$ & $1.50 \mathrm{E}-10$ & 10 & $1.00 \mathrm{E}-03$ & $3.00 \mathrm{E}-01$ & 1 & $1.05 \mathrm{E}-08$ & $9.056 \mathrm{E}-04$ \\
\hline
\end{tabular}


Table 2. Calculation for good contact between the Geomembrane and the underlying soil; $q=0.21 a^{0.1} \cdot h^{0.9} \cdot k_{s}^{0.74}$

\begin{tabular}{|c|c|c|c|c|c|c|c|}
\hline \multicolumn{2}{|c|}{ Hydraulic Conductivity of Subsoil } & \multicolumn{2}{|c|}{ Size of Hole in Geomembrane } & \multirow{2}{*}{$\begin{array}{c}\text { Head of Water } \\
\mathbf{m}\end{array}$} & \multirow{2}{*}{$\begin{array}{c}\text { Number of Holes } \\
\text { Holes/acre } \\
\end{array}$} & \multicolumn{2}{|c|}{ Flow Rate } \\
\hline $\mathrm{cm} / \mathrm{sec}$ & $\mathbf{m} / \mathbf{s e c}$ & $\mathbf{c m}^{2}$ & $\mathbf{m}^{2}$ & & & $\mathbf{m}^{3} / \mathbf{s e c}$ & $\mathrm{m}^{3} /$ day/acre \\
\hline $1.50 \mathrm{E}-08$ & $1.50 \mathrm{E}-10$ & 0.1 & $1.00 \mathrm{E}-05$ & $3.00 \mathrm{E}-01$ & 1 & $1.21 \mathrm{E}-09$ & $1.043 \mathrm{E}-04$ \\
\hline $1.50 \mathrm{E}-08$ & $1.50 \mathrm{E}-10$ & 0.1 & $1.00 \mathrm{E}-05$ & $3.00 \mathrm{E}-01$ & 30 & $3.62 \mathrm{E}-08$ & $9.391 \mathrm{E}-02$ \\
\hline $1.50 \mathrm{E}-08$ & $1.50 \mathrm{E}-10$ & 1 & $1.00 \mathrm{E}-04$ & $3.00 \mathrm{E}-01$ & 1 & $1.52 \mathrm{E}-09$ & $1.314 \mathrm{E}-04$ \\
\hline $1.50 \mathrm{E}-08$ & $1.50 \mathrm{E}-10$ & 1 & $1.00 \mathrm{E}-04$ & $3.00 \mathrm{E}-01$ & 30 & $4.56 \mathrm{E}-08$ & $1.182 \mathrm{E}-01$ \\
\hline $1.50 \mathrm{E}-08$ & $1.50 \mathrm{E}-10$ & 10 & $1.00 \mathrm{E}-03$ & $3.00 \mathrm{E}-01$ & 1 & $1.91 \mathrm{E}-09$ & $1.654 \mathrm{E}-04$ \\
\hline
\end{tabular}

Table 3. Flow rate Compacted Clay liner Only for leachate depth of $h=30 \mathrm{~cm}$ and compacted clay layer of $D=60 \mathrm{~cm}$ and $q=k_{s} \cdot \dot{i} \cdot A=K_{s}((h+D) / D) A$.

\begin{tabular}{cccc}
\hline Hydraulic Conductivity of Subsoil & \multicolumn{2}{c}{ Flow Rate } \\
\hline $\mathbf{c m} / \mathbf{s e c}$ & $\mathbf{m} / \mathbf{s e c}$ & $\mathbf{m}^{3} / \mathbf{s e c}$ & $\mathbf{m}^{3} /$ day/acre \\
\hline $1.50 \mathrm{E}-08$ & $1.50 \mathrm{E}-10$ & $2.25 \mathrm{E}-10$ & $7.867 \mathrm{E}-02$ \\
\hline
\end{tabular}

rate for a composite liner in good contact conditions ranges from $1.043 \times 10^{-4} \mathrm{~m}^{3} /$ day/acre for $0.1 \mathrm{~cm}^{2}$ are of hole in geomembrane and 1 hole/acre to $1.182 \times 10^{-1} \mathrm{~m}^{3} /$ day/acre for $1.0 \mathrm{~cm}^{2}$ area of hole in geomembrane and 30 hole/acre. The results show that the expected leachate rate for clay only liner is $7.86 \times 10^{-2} \mathrm{~m}^{3} /$ day/acre. Since the leakage rate for the case (of $0.1 \mathrm{~cm}^{2}$ area of hole in geomembrane and 1 hole/acre) is less than the leachate rate of clay only liner, it is recommended to use this system as composite liner.

\section{REFERENCES}

[1] R. Sharif and R. Stevens, "Building on Clay Soil in Jordan," Seminar Held at the Royal Scientific Society, Amman, 1983.

[2] ASTM D854-02 Standard Test Methods for Specific Gravity of Soils, "Annual Book of ASTM Standards, Section 4, Vol. 04.08, Soil and Rock; Building Stones," ASTM, Philadelphia, 1988.

[3] ASTM D4318-00 Standard Test Methods for Liquid Limit, Plasticity Limit, and Plasticity Index of Soils, "Annual Book of ASTM Standards, Section 4, Vol. 04.08, Soil and Rock; Building Stones," ASTM, Philadelphia, 1988.

[4] ASTM D698-00 Standard Test Methods for Laboratory Compaction Characteristics of soil Using Standard Effort $(12,400 \mathrm{ft}-$ Ibflft3 $(600 \mathrm{kN}-\mathrm{m} / \mathrm{m} 3))$, “Annual Book of ASTM Standards, Section 4, Vol. 04.08, Soil and Rock; Building Stones," ASTM, Philadelphia, 1988.
[5] ASTM D5856-95 Standard Test Method for Measurement of Hydraulic Conductivity of Porous Material Using a Rigid-Wall, Compaction-Mold Permeameter, "Annual Book of ASTM Standards, Section 4, Vol. 04.08, Soil and Rock; Building Stones," ASTM, Philadelphia, 2002.

[6] ASTM D427-04 Test Method for Shrinkage Factors of Soils, "Annual Book of ASTM Standards, Section 4, Vol. 04.08, Soil and Rock; Building Stones," ASTM, Philadelphia, 1988.

[7] D. E. Daniel and C. H. Benson, "Water Content-Density Criteria for Compacted Soil Liners," Journal of Geotechnical Engineering, Vol. 116, No. 12, 1990, pp. 1811-1830. http://dx.doi.org/10.1061/(ASCE)0733-9410(1990)116:12 $\underline{(1811)}$

[8] D. E. Daniel and Y.-K. Wu, "Compacted Clay Liners Covers for Arid Sites," Journal of Geotechnical Engineering, Vol. 119, No. 2, 1993, pp. 223-237. http://dx.doi.org/10.1061/(ASCE)0733-9410(1993)119:2( 223)

[9] H. Akgün and R. B. Wallace, "Utilization of Ankara Clay for Sanitary Landfill Bottom Liners, Turkey," Journal of Solid Waste Technology and Management, Vol. 4, 2005, pp. 193-197.

[10] J. P. Giroud and R. Bonaparte, "Leakage through Liners Constructed with Geomembranes, Part 2. Composite Liners," Geotextiles and Geomembranes, Vol. 8, 1989, pp. 71-111.

[11] J. P. Giroud, A. Khatami and K. Badu-Tweneboah, "Evaluation of Leakage through Composite Liners," Geotextile and Geomembranes, Vol. 8, Elsevier Science Publisher Ltd., England, 1989, pp. 333-340.

[12] Q. Xuede, R. Koerner and D. Gray, "Geotechnical Aspects of Landfill Design and Construction," Prentice Hall Publisher, New Jersy, 2002.

[13] USEPA, "Criteria for Municipal Solid Waste Landfills (MSWLF Criteria), 40 CFR, Part 258," Cincinnati, Ohio, 1993. 